\title{
KORELASI INDEKS MASA TUBUH (IMT) DENGAN TEKANAN DARAH
}

\author{
Angelia Friska Tendean \\ Fakultas Keperawatan Universitas Klabat \\ angelia.tendean@unklab.ac.id
}

\begin{abstract}
Hypertension has become a serious problem in worldwide. The most factor causes hypertension is obesity or overweight. The main purpose of this study was to determine correlation Body Mass Index (BMI) and blood pressure at Kinamang Village. The design in this study was cross sectional study. The sample was used non probability sampling with accidental sampling technique. Sample of this study were 89 respondents. The results were showed most category BMI were normal category 48,3\%, systolic and diastolic category were prehypertension 53,9\% and 34,8\%. The analysis was using spearman correlation and the result showed BMI and systolic $p$ value 0,001 $<0,05$ with $r=0,360$ and diastolic $p 0,000<0,05$ with $r=0,389$. The conclusion is there was statistically significant positive correlation between BMI and blood pressure both systolic and diastolic. The higher BMI then blood pressure will increase both systolic and diastolic.
\end{abstract}

Keywords: Body Mass Index; Blood Pressure

\begin{abstract}
Abstrak
Hipertensi sudah menjadi masalah yang serius di dunia. Obesitas atau kelebihan berat badan merupakan salah satu faktor yang paling sering menyebabkan hipertensi. Tujuan dari penelitian ini untuk mengetahui hubungan Indeks Masa Tubuh (IMT) dan tekanan darah di desa Kinamang. Desain penilitian yang digunakan menggunakan cross sectional. Pengambilan sampel menggunakan non probability samping dengan teknik pengambilan accidental sampling dengan jumlah sampel yang didapat 89 responden. Hasil penelitian yang didapat kategori Indeks masa tubuh terbanyak dalam kategori normal 48,3\%, kategori tekanan darah sistolik terbanyak kategori prehipertensi 53,9\% dan kategori tekanan darah diastolik terbanyak kategori prehipertensi 34,8\%. Hasil analisa korelasi menggunakan spearman correlation didapati korelasi IMT dengan tekanan darah sistolik p 0,001<0,05 dengan $r=0,360$ dan korelasi IMT dengan tekanan darah diastolik p $0,000<0,05$ dengan $r=0,389$. Kesimpulan ada hubungan yang signifikan antara IMT dengan tekanan darah sistolik maupun diastolik. Semakin meningkat IMT maka tekanan darah sistolik maupun diastolik akan meningkat.
\end{abstract}

Kata Kunci: Indeks Masa Tubuh; Tekanan Darah

\section{PENDAHULUAN}

Hipertensi sudah menjadi masalah kesehatan global. Hipertensi adalah tekanan darah yang lebih dari atas normal yaitu sistolik $140 \mathrm{mmHg}$ dan diastolik $90 \mathrm{mmHg}$, yang terbagi menjadi dua kategori yaitu hipertensi primer atau esensial (tidak diketahui penyebabnya) dan hipertensi sekunder (penyakit ikutan dari penyakit yang diderita sebelumnya) dimana sekitar $90 \%$ penderita tergolong hipertensi primer dan $10 \%$ penderita tergolong hipertensi sekunder (Tarigan, Lubis, \& Syarifah, 2018). . Survei data World Health Organization (WHO) tahun 2015 menunjukkan sekitar 1,13 milyar penduduk di dunia menderita hipertensi, yang 
artinya ada 1 dari 3 orang di dunia terdiagnosis hipertensi, dan berdasarkan data Riset Kesehatan Dasar tahun 2018 di Indonesia prevalensi hipertensi $34,1 \%$ dengan prevalensi hipertensi berdasarkan diagnosa dokter pada penduduk Indonesia usia $\geq 18$ tahun tertinggi di Sulawesi Utara 13,2\% (KEMENKES, 2019).

Ada beberapa faktor yang mempengaruhi terjadi hipertensi diantaranya obesitas, ras, umur, asupan garam yang tinggi, dan adanya riwayat hipertensi dalam keluarga (Sylvestris, 2014) Berat Badan berlebih dan obesitas adalah satu dari faktor resiko hipertensi yang paling banyak (Emha, Yusra, \& Syamsun, 2015;Hall, do Carmo, da Silva, Wang, \& Hall, 2015). Obesitas adalah akumulasi abnormal lemak tubuh lebih dari $20 \%$ dari berat badan ideal (Jiang, Lu, Zong, Ruan, \& Liu, 2016). Prevalensi obesitas semakin meningkat. Sekitar $1 / 3$ penduduk dunia mengalami kelebihan berat badan dan diperkirakan tahun $2030 \quad 38 \%$ penduduk dunia akan mengalam kelebihan berat badan dan $20 \%$ akan mengalami obesitas (Hruby \& Hu, 2016). Menurut hasil Riset Kesehatan Dasar tahun 2018 tingkat obesitas pada orang dewasa di indonesia meningkat menjadi $21,8 \%$ yang sebelumnya tahun 2013 berjumlah $14,8 \%$, begitu juga prevalensi kelebihan berat badan meningkat menjadi 13,6\% yang sebelumnya tahun 2013 berjumlah $11,5 \%$, dimana prevalensi obesitas paling tinggi berada di Sulawesi Utara sebanyak 30,2\% (Rossa \& Nodia, 2018).

Obesitas ataupun kelebihan berat badan merupakan suatu hal yang tidak bisa disepelekan. Penelitian sebelumnya menunjukkan ada hubungan antara peningkatan indeks masa tubuh dengan peningkatan tekanan darah baik sistolik dan diastolik (Dua, Bhuker, Sharma, Dhall, \& Kapoor, 2014, Shihab, et al., 2012' Natalia, Hasibuan \& Hendro, 2014; Vuvor, 2017). Indeks masa tubuh merupakan perhitungan antara berat badan dan tinggi badan seseorang yang dapat menjadi indikator kadar adipositas dalam tubuh seseorang (Setyawati \& Hartini, 2018). Menurut Kotchen ( 2010) obesitas mengakibatkan resistensi insulin, retensi sodium, meningkatkan aktivitas sistem saraf simpatetik, mengaktifkan hormon angiotensin-aldosteron dan mengubah fungsi pembuluh darah .

Hipertensi sering juga disebut sebagai the silent killer. Hipertensi diperkirakan akan menjadi penyebab kematian 7,1 juta jiwa atau sekitar 13 persen di dunia, dimana hipertensi yang tidak terkontrol 7 kali lebih beresiko terserang penyakit strok, 6 kali lebih beresiko terkena gagal jantung kongestif dan 3 kali lebih beresiko terkena serangan jantung (Emha, Yusra, \& Syamsun, 2015). IMT diatas normal yaitu kelebihan berat badan dan obesitas menjadi penyebab utama hipertensi (Hall, do Carmo, da Silva, Wang, \& Hall, 2015). Orang-orang kadang tidak menyadari dampak IMT diatas normal yang dapat membahayakan kesehatan termasuk penyakit Hipertensi. Berdasarkan observasi terhadap beberapa masyarakat di desa Kinamang yang memiliki tekanan darah tinggi beberapa masyarakat tersebut memiliki IMT diatas normal. Adapun tujuan dari penelitian ini untuk mengetahui apakah ada hubungan indeks masa tubuh dengan tekanan darah pada masyarakat di desa Kinamang.

\section{METODOLOGI PENELITIAN}

Metode penelitian yang digunakan adalah menggunakan survei analitik dengan pendekatan cross sectional. Penelitian ini dilaksanakan pada bulan Juli tahun 2017. Peneliti menggunakan Analisis Univariate dengan menyajikan distribusi frekuensi dan persentase dari variabelvariabel yang diteliti, untuk memperoleh gambaran pada masing-masing variabel yang diteliti dan disajikan dengan menggunakan tabel dan distribusi frekuensi. Peneliti juga menggunakan Analisis Bivariate untuk menganalisis dua variabel yang diduga mempunyai hubungan atau berkolerasi, dengan uji statistik Spearman Correlation.

Populasi dalam penelitian ini adalah masyarakat yang tinggal di desa Kinamang yang berusia 2089 tahun. Sampel penelitian menggunakan non probability sampling dengan teknik 
pengambilan accidental sampling. Menurut Kumar (2019) accidental sampling adalah sampel yang diambil secara kebetulan bertemu sesuai dengan kriteria peneliti dan jumlah sampel ditentukan sendiri oleh peneliti.

Prosedur pengumpulan data yang dilakukan peneliti antara lain: 1) membuat surat ijin meneliti di Fakultas Keperawatan, 2) memasukkan surat ijin kantor kepala desa Kinamang, 3) memperoleh ijin dari kepala desa, 4) menjelaskan maksud dan tujuan penelitian kepada responden dan memberikan informed consent, 5) melakukan pengukuran berat badan dan tinggi badan, serta mengukur tekanan darah, 6) Mengolah data, dan 7) Ucapan terimakasih kepada responden dan kepala desa.

Alat ukur yang digunakan dalam penelitian ini menggunakan timbangan berat badan, meteran untuk mengukur indeks masa tubuh dan stetoskop dan sphygmomanometer (Anaroid) untuk mengukur tekanan darah dan lembar observasi. Hasil pengukuran indeks masa tubuh didapati berdasarkan rumus perhitungan indeks masa tubuh berat badan $(\mathrm{kg})$ bahagi tinggi badan $(m)^{2}$ yang kemudian dikategorikan sesuai kategori penduduk Asia pada tabel 1.

Tabel 1

Kategori Indeks Masa Tubuh Asia

\begin{tabular}{cc}
\hline Indeks Masa Tubuh & Kategori \\
\hline$<18,5$ & Berat Badan Dibawah \\
$18,5-22,9$ & Normal \\
$23,0-24,9$ & Kelebihan Berat Badan \\
$25,0-29,9$ & Obesitas I \\
$\geq 30$ & Obesitas II \\
\hline
\end{tabular}

Sumber: Setyawati dan Hartini, 2018

Perhitungan tekanan darah dikategorikan berdasarkan klasifikasi dari The seven Joint National Commette (JNC-7). Klasifikasi hipertensi dapat dilihat pada tabel 2 .

Tabel 2.

Klasifikasi Hipertensi JNC-7

\begin{tabular}{lcc}
\hline \multicolumn{1}{c}{ Klasifikasi } & Sistolik & Diastolik \\
\hline Normal & $<120$ & $<80$ \\
Prehipertensi & $120-139$ & $80-84$
\end{tabular}

\begin{tabular}{llc} 
Hipertensi St.1 & $140-159$ & $90-99$ \\
Hipertensi St.2 & $160-179$ & $100-109$ \\
\hline
\end{tabular}

Sumber: Tjokroprawiro, Setiawan, Santoso, Sogiarto, dan Rahmawati, 2015.

\section{HASIL}

Total responden yang didapat berjumlah 89 responden. Hasil penelitian dapat dilihat pada tabel-tabel dibawah.

Tabel 3.

Distribusi Frekuensi dan persentase Responden berdasarkan Data demografi

\begin{tabular}{lcc}
\hline \multicolumn{1}{c}{ Kategori } & Frekuensi & Persentase \\
\hline Usia & 16 & 18 \\
20-29 tahun & 13 & 14,6 \\
30-39 tahun & 27 & 30,3 \\
$40-49$ tahun & 9 & 10,1 \\
50-59 tahun & 17 & 19,1 \\
60-69 tahun & 7 & 7,9 \\
70-79 tahun & & \\
Gender & 30 & 33,7 \\
Laki-laki & 59 & 66,3 \\
Perempuan & & \\
Pendidikan & & \\
Terakhir & 2 & 2,2 \\
Tidak Sekolah & 12 & 13,5 \\
Tidak tamat SD & 20 & 22,5 \\
Tamat SD & 23 & 25,8 \\
Tamat SMP & 24 & 27,0 \\
Tamat SMA & 8 & 9,0 \\
Tamat & & \\
Diploma/Sarjana & & \\
Pekerjaan & 8 & 9,0 \\
Tidak bekerja & 2 & 2,2 \\
PNS & 5 & 5,6 \\
Pegawai Swasta & 1 & 1,1 \\
Pensiunan & 12 & 13,5 \\
Wiraswasta & 61 & 68,5 \\
Lainnya & & \\
\hline
\end{tabular}

Tabel 3 menunjukan hasil penelitian dari data demografi yang dikumpulkan peneliti melalui kuesioner. Berdasarkan distribusi frekuensi menurut usia didapati responden terbanyak berusia antara 40-49 tahun dengan jumlah responden 27 (30,3\%), menurut gender atau 

pendidikan terakhir responden terbanyak adalah responden tamat SMA 24 (27\%) dan menurut pekerajaan responden terbanyak bekerja pada kategori lainnya $61(68,5 \%)$.

\begin{tabular}{lcc}
\hline \multicolumn{1}{c}{ Diastolik } & Frekuensi & Persentase \\
\hline Normal & 26 & 29,2 \\
Prehipertensi & 31 & 34,8 \\
Hipertensi St.1 & 26 & 29,2 \\
Hipertensi St.2 & 6 & 6,7 \\
\hline
\end{tabular}

Tabel 4.

Distribusi frekuensi dan persentase tekanan darah sistolik

Berdasarkan tabel 5 hasil distribusi frekuensi dan persentase responden berdasarkan diastolik terbanyak yaitu kategori prehipertensi 31 responden $(34,8 \%)$.

\begin{tabular}{lcc}
\hline \multicolumn{1}{c}{ Sistolik } & Frekuensi & Persentase \\
\hline Normal & 22 & 24,7 \\
Prehipertensi & 48 & 53,9 \\
Hipertensi St.1 & 18 & 20,2 \\
Hipertensi St.2 & 1 & 1,1 \\
\hline
\end{tabular}

Berdasarkan tabel 4 hasil distribusi frekuensi dan persentase responden berdasarkan diastolik terbanyak yaitu kategori prehipertensi 48 responden $(53,9 \%)$.

Tabel 5.

Distribusi Frekuensi dan persentase Responden berdasarkan diastolik

Tabel 6.

Distribusi Frekuensi dan persentase Indeks Masa Tubuh

\begin{tabular}{lcc}
\hline \multicolumn{1}{c}{ Kategori } & Frekuensi & Persentase \\
\hline Berat Badan & 4 & 4,5 \\
Dibawah & & \\
Normal & 43 & 48,3 \\
Kelebihan Berat & 17 & 19,1 \\
Badan & & \\
Obesitas I & 25 & 28,1 \\
\hline
\end{tabular}

Berdasarkan tabel 6 hasil distribusi frekuensi dan persentase Indeks masa tubuh terbanyak yaitu kategori normal 43 responden $(48,3 \%)$, kedua terbanyak obesitas I 25 responden $(28,1 \%)$.

Tabel 7.

Tabulasi silang IMT dengan tekanan darah sistolik dan diastolik 
Berdasarkan tabel 7 dapat dilihat hasil tabulasi

disusul Obesitas I dengan kategori prehipertensi

\begin{tabular}{|c|c|c|c|c|c|}
\hline IMT & Normal & Pre Hipertensi & $\begin{array}{l}\text { Hipertensi } \\
\text { St.1 }\end{array}$ & $\begin{array}{l}\text { Hipertensi } \\
\text { St.2 }\end{array}$ & Total \\
\hline \multicolumn{6}{|l|}{ Sistolik } \\
\hline BB Dibawah Normal & $\begin{array}{r}2 \\
9.1 \%\end{array}$ & $\begin{array}{r}1 \\
2.1 \%\end{array}$ & $\begin{array}{r}1 \\
5.6 \%\end{array}$ & $\begin{array}{r}0 \\
.0 \%\end{array}$ & $\begin{array}{r}4 \\
4.5 \%\end{array}$ \\
\hline \multirow[t]{2}{*}{ Normal } & 17 & 22 & 4 & 0 & 43 \\
\hline & $77.3 \%$ & $45.8 \%$ & $22.2 \%$ & $.0 \%$ & $48.3 \%$ \\
\hline \multirow[t]{2}{*}{ Kelebihan BB } & 0 & 11 & 5 & 1 & 17 \\
\hline & $.0 \%$ & $22.9 \%$ & $27.8 \%$ & $100.0 \%$ & $19.1 \%$ \\
\hline \multirow[t]{2}{*}{ Obesitas I } & 3 & 14 & 8 & 0 & 25 \\
\hline & $13.6 \%$ & $29.2 \%$ & $44.4 \%$ & $.0 \%$ & $28.1 \%$ \\
\hline
\end{tabular}

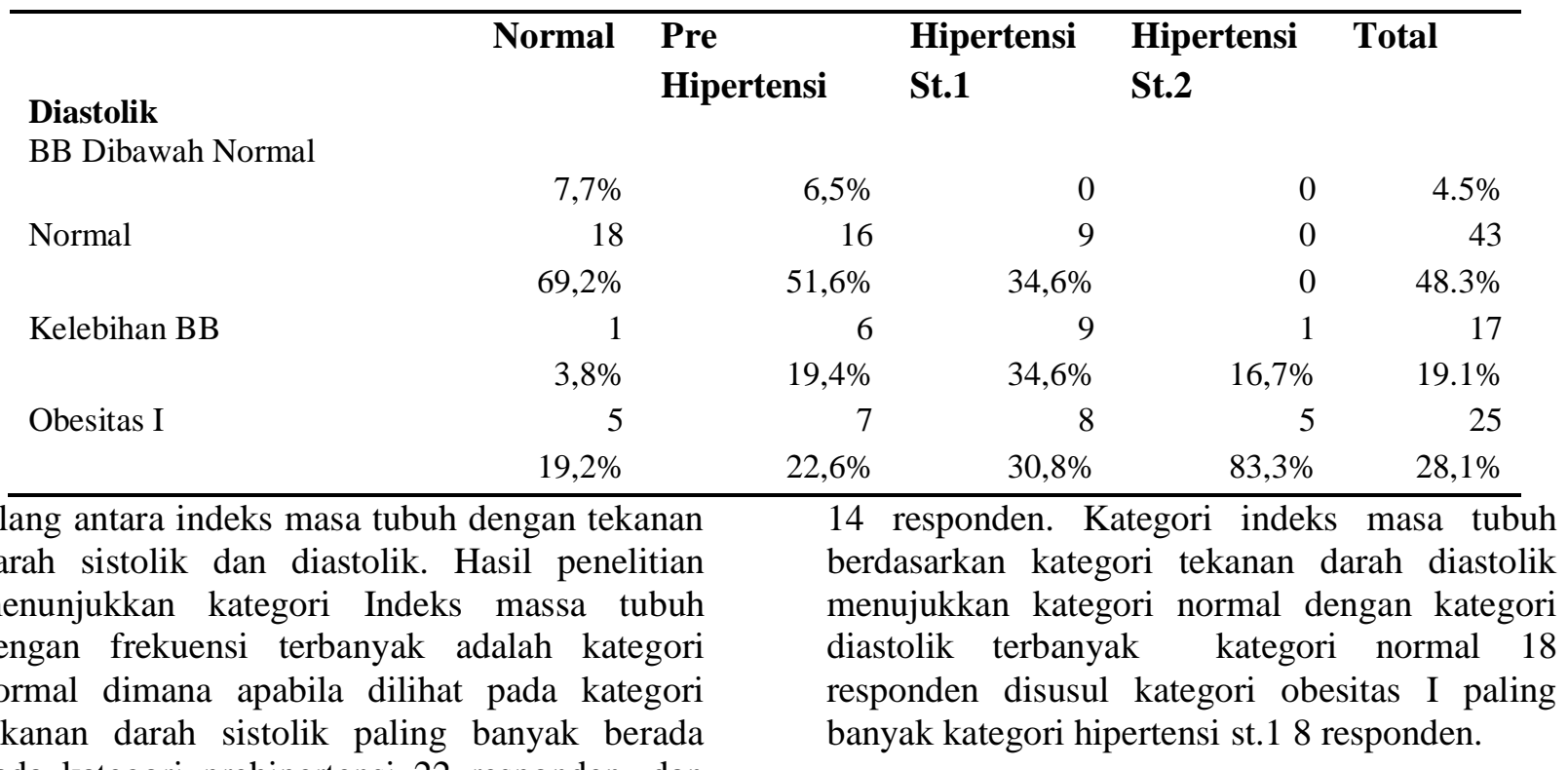

Tabel 8.

Tabulasi silang Usia dengan tekanan darah sistolik dan diastolik 


\begin{tabular}{|c|c|c|c|c|c|}
\hline Usia & Normal & Pre Hipertensi & $\begin{array}{l}\text { Hipertensi } \\
\text { St.1 }\end{array}$ & $\begin{array}{c}\text { Hipertensi } \\
\text { St.2 }\end{array}$ & Total \\
\hline \multicolumn{6}{|l|}{ Sistolik } \\
\hline \multirow[t]{2}{*}{$20-29$} & 10 & 6 & 0 & 0 & 16 \\
\hline & $62,5 \%$ & $37,5 \%$ & 0 & 0 & $100 \%$ \\
\hline \multirow[t]{2}{*}{$30-39$} & 2 & 11 & 0 & 0 & 13 \\
\hline & $15,4 \%$ & $84,6 \%$ & 0 & 0 & $100 \%$ \\
\hline \multirow[t]{2}{*}{$40-49$} & 5 & 11 & 11 & 0 & 27 \\
\hline & $18,5 \%$ & $40,7 \%$ & $40,7 \%$ & 0 & $100 \%$ \\
\hline \multirow[t]{2}{*}{$50-59$} & 3 & 6 & 0 & 0 & 9 \\
\hline & $33,3 \%$ & $66,7 \%$ & 0 & 0 & $100 \%$ \\
\hline \multirow[t]{2}{*}{$60-69$} & 2 & 10 & 4 & 1 & 17 \\
\hline & $11,8 \%$ & $58,8 \%$ & $23,5 \%$ & $5,9 \%$ & $100 \%$ \\
\hline \multirow[t]{2}{*}{$70-79$} & 0 & 4 & 3 & 0 & 7 \\
\hline & 0 & $57,1 \%$ & $42,9 \%$ & 0 & $100 \%$ \\
\hline \multicolumn{6}{|l|}{ Diastolik } \\
\hline \multirow[t]{2}{*}{$20-29$} & 7 & 9 & 0 & 0 & 16 \\
\hline & $43,8 \%$ & $56,3 \%$ & 0 & 0 & $100 \%$ \\
\hline \multirow[t]{2}{*}{$30-39$} & 2 & 3 & 8 & 4 & 13 \\
\hline & $15,4 \%$ & $23,1 \%$ & $61,5 \%$ & $14.8 \%$ & $100 \%$ \\
\hline \multirow[t]{2}{*}{$40-49$} & 10 & 5 & 8 & 0 & 27 \\
\hline & $37,0 \%$ & $18,5 \%$ & $29,6 \%$ & 0 & $100 \%$ \\
\hline \multirow[t]{2}{*}{$50-59$} & 3 & 2 & 4 & 2 & 9 \\
\hline & $33,3 \%$ & $22,2 \%$ & $44,4 \%$ & $11.8 \%$ & $100 \%$ \\
\hline \multirow[t]{2}{*}{$60-69$} & 3 & 8 & 4 & 0 & 17 \\
\hline & $17,6 \%$ & $47,1 \%$ & $23,5 \%$ & 0 & $100 \%$ \\
\hline \multirow[t]{2}{*}{$70-79$} & 1 & 4 & 2 & 0 & 7 \\
\hline & $14,3 \%$ & $57,1 \%$ & $28,6 \%$ & 0 & $100 \%$ \\
\hline
\end{tabular}

Berdasarkan tabel 8 dapat dilihat hasil tabulasi silang antara usia dengan tekanan darah sistolik dan diastolik. Hasil penelitian menunjukkan frekuensi kategori usia paling banyak pada tekanan darah sistolik berada pada beberapa kategori usia 30-39 tahun 11 responden kategori prehipertensi, 40-49 tahun 11 responden kategori prehipertensi dan 11 responden juga berada pada kategori Hipertensi St.1
Hasil penelitian menunjukkan frekuensi kategori usia paling banyak pada tekanan darah diastolik adalah kategori normal pada usia 40-49 tahun sebanyak 10 responden, dan disusul kategori usia 20-29 tahun dalam kategori prehipertensi 9 responden. 
Tabel 9.

Tabulasi silang Gender dengan tekanan darah sistolik dan diastolik

\begin{tabular}{lrrrrr}
\hline Gender & Normal & Pre Hipertensi & Hipertensi St.1 & Hipertensi St.2 & Total \\
\hline Sistolik & & & & & \\
Laki-laki & 7 & 19 & $10.0 \%$ & 1 & 30 \\
& $23,3 \%$ & $63,3 \%$ & 15 & $3,3 \%$ & $100 \%$ \\
Perempuan & 15 & 29 & $25,4 \%$ & 0 & 59 \\
& $25,4 \%$ & $49,2 \%$ & 0 & $100 \%$ \\
\hline Gender & Normal & Pre Hipertensi & Hipertensi St.1 & Hipertensi St.2 & \\
\hline Diastolik & & & 6 & 1 & 30 \\
Laki-laki & 9 & 14 & $20.0 \%$ & $3,3 \%$ & $100 \%$ \\
Perempuan & $30,0 \%$ & $46,7 \%$ & 20 & 5 & 59 \\
& 17 & 17 & $33,9 \%$ & $8,5 \%$ & $100 \%$ \\
\hline
\end{tabular}

Berdasarkan tabel 9 dapat dilihat hasil tabulasi silang antara gender dengan tekanan darah sistolik dan diastolik. Hasil penelitian menunjukkan kategori gender pada tekanan darah sistolik frekuensi terbanyak adalah kategori perempuan dengan prehipertensi sebanyak 29 responden. Hasil penelitian menunjukkan kategori gender pada tekanan darah diastolik frekuensi terbanyak adalah kategori perempuan dengan hipertensi st.1 sebanyak 20 responden.

Hasil uji bivariat menggunakan Spearman correlation didapati korelasi antara IMT dengan tekanan darah sistolik yaitu $\mathrm{p}$ value $0,001<0.05$ dengan koefisien korelasi $\mathrm{r}$ 0,360. Korelasi antara indeks masa tubuh dengan tekanan darah diastolik yaitu $\mathrm{p}$ value $0,000<0,05$ dengan $\mathrm{r}$ 0,389 . Artinya, ada korelasi yang significant antara IMT dan tekanan darah (sistolik dan diastolik), masing-masing korelasi IMT dengan tekanan darah sistolik dan diastolik memiliki korelasi positif (semakin meningkatnya IMT maka tekanan darah juga akan semakin meningkat) dan kekuatan korelasi yang dihasilkan yaituyang cukup.

\section{PEMBAHASAN}

Hasil peneliitan menujukkan berdasarkan data demografi frekuensi responden terbanyak berada pada kategori usia 40-49 tahun dengan jumlah responden 27 (30,3\%). Frekuensi usia berdasarkan tekanan darah sistolik terbanyak berada pada beberapa kategori usia 30-39 tahun 11 responden kategori prehipertensi, 40-49 tahun 11 responden kategori prehipertensi dan 11 responden juga berada pada kategori Hipertensi St.1. Frekuensi usia berdasarkan tekanan darah diastolik dapat dilihat frekuensi paling banyak berada pada kategori normal dengan paling banyak pada usia kategori 40-49 tahun sebanyak 10 responden.

Menurut (Lionakis, Mendrinos, Sanidas, Favatas, \& Georgopoulou, 2012) usia merupakan bagian dalam kehidupan yang tidak dapat dipungkiri bisa menyebabkan dua hal yang tidak menyenangkan yaitu penurunan fisiologis tubuh dan rentan terhadap penyakit. Insiden hipertensi paling sering terjadi pada usia lansia diatas 65 tahun (Buford, 2016). Pertambahan usia menyebabkan struktur pembuluh darah menjadi sempit dan dinding pembuluh darah menjadi kaku sehingga terjadi peningkatan tekanan darah (Novitaningsih, 2014). Menurut pemberitaan CNN Indonesia (2019) hipertensi 
dapat terjadi pada siapa saja termasuk pada generasi milinial pada usia 18 sampai 39 tahun.

Jenis kelamin berkaitan erat dengan hipertensi. Hasil penelitian menujukkan responden terbanyak adalah responden perempuan 59 $(66,3 \%)$ dimana peningkatan tekanan darah sistolik maupun diastolik paling banyak terjadi pada perempuan. Menurut (Sandberg \& Jin, 2012) faktor biologi perempuan seperti hormon sex, koromosom dan lainnya berperan penting bagi perempuan untuk melawan terjadinya hipertensi. Perempuan menghasilkan hormon estrogen yang berfungsi untuk meningkatkan kadar High Density Lipoprotein (HDL) yang berperan mencegah terjadinya proses aterosklerosis yang dapat memicu terjadinya peningkatan tekanan darah Pada saat perempuan berada dalam keadaan menopause produksi hormone estrogen akan berkurang sehingga perempuan menjadi rentan terhadap penyakit termasuk hipertensi (Anggraini, 2012).

Indeks masa tubuh merupakan pengukuran berat badan dan tinggi badan yang menggambarkan kadar lemak tubuh (Setyawati \& Hartini, 2018). Hasil penelitian menujukkan frekuensi Indeks masa tubuh terbanyak yaitu kategori normal 43 responden $(48,3 \%)$, kedua terbanyak obesitas I 25 responden $(28,1 \%)$. Berdasarkan hasil tabulasi silang Indeks masa tubuh dengan tekanan darah didapati kategori tekanan darah sistolik paling banyak berada pada kategori normal dengan kategori prehipertensi 22 responden, dan disusul Obesitas I dengan kategori prehipertensi 14 responden. Kategori indeks masa tubuh berdasarkan kategori tekanan darah diastolik menujukkan kategori normal dengan kategori diastolik terbanyak kategori normal 18 responden disusul kategori obesitas I kategori hipertensi st. 18 responden.

Indeks masa tubuh diatas normal sering mengakibatkan berbagai macam penyakit diantaranya penyakit jantung dan pembuluh darah, diabetes mellitus, kanker, osteoartritis dan juga penyakit hipertensi (Ardania, 2012). Sekitar $65-75 \%$ penyebab hipertensi paling banyak disebabkan oleh faktor resiko Indeks
Masa Tubuh diatas normal. Peningkatan tekanan darah terjadi karena adanya peningkatan reabsorpsi di tubular ginjal, sehingga mengakibatkan tekanan natriuresis rusak dan terjadi ekspansi volume karena aktivasi oleh Sistem saraf simpatik dan sistem reninangiotensi aldosteron dan akibat terjadi tekanan fisik di ginjal yang diakibatkan oleh obesitas viseral (Hall M. , do Carmo, da Saliva, Juncos, Wang, \& Hall, 2014).

Hasil penelitian korelasi antara IMT dengan tekanan darah sistolik maupun diastolik menujukkan nilai $\mathrm{p}$ pada tekanan darah sistolik $\mathrm{p}=0,001$ dan diastolik $\mathrm{p}=0,000$ masing-masing lebih kecil $\mathrm{p}=0,05$, artinya secara statistik ada korelasi yang signifikan antara IMT dan tekanan darah sistolik dan diastolik. Hasil koefisien korelasi menujukkan nilai r 0,360 pada tekanan darah sistolik dan nilai r 0,389 pada tekanan darah diastolik, artinya indeks masa tubuh dengan tekanan darah sistolik dan diastolik memiliki kekuatan hubungan yang cukup. Hasil penelitian juga menujukkan korelasi yang dihasilkan antara indeks masa tubuh dengan tekanan darah memiliki korelasi positif. Artinya apabila indeks masa tubuh meningkat maka tekanan darah juga akan meningkat.

Hasil penelitian ini sejalan dengan penelitianpenelitian yang dilakukan sebelumnya tentang indeks masa tubuh dan tekanan darah yang telah dibuktikan memiliki hubungan yang signifikan baik itu tekanan darah sistolik maupun tekanan darah sistolik (Dua, Bhuker, Sharma, Dhall, \& Kapoor, 2014, Shihab, et al., 2012 Natalia, Hasibuan \& Hendro, 2014; Vuvor, 2017). Menurut Dua, Bhuker, Sharma, Dhall, dan Kapoor, (2014) kelebihan berat badan ataupun obesitas lebih beresiko mengalami peningkatan tekanan darah dibandingkan dengan mereka yang memiliki indeks masa tubuh normal. Menurut Kotchen ( 2010) ketika seseorang memiliki IMT diatas normal, maka lemak yang tubuh akan menyebabkan retensi sodium, meningkatkan aktivitas sistem saraf simpatetik, mengaktifkan hormon angiotensin-aldosteron dan mengubah fungsi pembuluh darah dan pada akhirnya tekanan darah akan meningkat . 


\section{KESUMPULAN DAN SARAN}

Responden terbanyak dalam penelitian ini masuk dalam kategori prehipertensi baik tekanan darah sistolik dan diastolik. Peningkatan indeks masa tubuh cenderung mengalami peningkatan tekanan darah sistolik dan diastolik. Hasil penelitian menujukkan bahwa ada hubungan yang signifikan antara indeks masa tubuh dengan tekanan darah sistolik, dimana peningkatan indeks masa tubuh akan lebih beresiko mengalami hipertensi dibandingkan dengan indeks masa tubuh normal.

Saran bagi masyarakat untuk tetap menjaga berat badan tetap ideal dengan memodifikasi gaya hidup. Bagi peneliti selanjutnya dapat meneliti hubungan aktivitas olahraga dengan IMT dan hipertensi.

\section{REFERENSI}

Anggraini. (2012). Jenis kelamin penderita hipertensi. Bandung: PT Remaja Rosida Karya.

Ardania, S. (2012). Hubungan Indeks Masa Tubuh dengan tekanan darah pada masyarakat di kelurhan Pakuncen Wirobrajan Yogyakarta. Program Studi Ilmu Keperawatan Sekolah Tinggi Ilmu Kesehatan 'Aisyiyah Yogyakarta, Naskah Publikasi.

Buford, T. (2016). Hypertension and aging. Ageing Research Review.Vol.26, 96111. doi:10.1016/j.arr.2016.01.007.

CNN Indonesia. (2019, Maret 5). Generasi Milenial Rentan Hipertensi. Jakarta Selatan, Jakarta, Indonesia.

Dua, S., Bhuker, M., Sharma, P., Dhall, M., \& \& Kapoor, S. (2014). Body Mass Index related to blood pressure among adults.
North Amercan Journal of Medical

Sciences.Vol.6 (2)., 89-

95.doi:10.4103/1947-2714.127751.

Dua, S., Bhuker, M., Sharma, P., Dhall, M., \&

Kapoor, S. (2014). Body mass index related to blood pressure among adults. North american journal of medical sciences.6(2), 89-95.doi:10.4103/19472714.127751 .

Emha, H. A., Yusra, P., \& Syamsun, A. (2015). Relationship Between Body Mass Index (BMI) and Blood Pressure in NTB

General Hospital. Journal of

Hypertension.Vol.33., p e

21.doi:10.1097/01.hjh.0000469791.

Hall, J., do Carmo, J., da Silva, A., Wang, Z., \& Hall, M. (2015). Obesity-Induced

Hypertension. American Journa Association Journal. Vol.116, 991-1006.

Hall, M., do Carmo, J., da Saliva, A., Juncos, L., Wang, Z., \& Hall, J. (2014). Obesity, hypertension and chronic kidney disease. International Journal of Nephrology and Renavascular Disease.Vol:2014, 7588.doi:10.2147/IJNRD.S39739.

Hruby, A., \& Hu, F. B. (2016). The epidemiology of obesity: a big picture. Pharmacoeconomics.Vol.33.Issue 7, 673-689.doi:10.1007/s40273-014-0243$\mathrm{x}$.

Jiang, S.-Z., Lu, W., Zong, X.-F., Ruan, H.-Y., \& Liu, Y. (2016). Obesity and Hypertension. Exp Ther Med.Vol 12.Issue 4, 23952399.doi:10.3892/etm.2016.3667

KEMENKES. (2019, Mei 17). Kementrian Kesehatan Republik Indonesia. 
Retrieved September 05, 2019, from Kementrian Kesehatan Republik Indonesia: http://www.depkes.go.id.

Kotchen, T. A. (2010). Obesity-Related hypertension:Epidemiology, pathophysiologi and clinical management. American Journal of Hypertension.Vol.23.Issue 11, 11701178.doi:10.1038/ajh.2010.172.

Kumar, Ranjit. (2019). Research methodelogy:step by step guide for beginning.Edisi 5. London: SAGE publication.

Lionakis, N., Mendrinos, D., Sanidas, E., Favatas, G., \& Georgopoulou, M. (2012). Hypertension in the elderly. World Journal of Cardiology. Vol.4.No.5, 135147.doi:10.4330//wjc.V4.i5.135.

Novitaningsih, T. (2014). Hubungan karakteristik(umur,jenis kelamin, tingkat pendidikan) dan aktivitas fisik dengan tekanan darah pada lansia di kelurahan makamhaji kecamatan Kartasura Kabupaten Sukohardjo. Program Studi Gizi Fakultas Ilmu Kesehatan Universitas Muhammadiyah Surakarta. Naskah publikasi

Rossa, V., \& Nodia, F. (2018, November 02). health.men. Retrieved September 05, 2019, from suara.com: http://www.suara.com

Sandberg, K., \& Jin, H. (2012). Sex difference in primary hypertension. Biological of sex difference. 3(7), doi:10.1186/20426410-3-7.
Setyawati, V., \& Hartini, E. (2018). Buku ajar dasar ilmu gizi kesehatan masyarakat.Ed.1. Yogyakarta: Deepublish.

Shihab, H. M., Meoni, L. A., Chu, A. Y., Wang, N.-Y., Ford, D., Liang, K.-Y., et al. (2012). Body mass index and risk of incident hypertension over the life course. American heart Association Journal.Vol.126, 2983-2989.

Sylvestris, A. (2014). Hypertension and retinopathy hypertension. E Journal Universitas Muhamadiyah Malang.Vol.10.No.1, 1-9.

Tarigan, A. R., Lubis, Z., \& Syarifah. (2018). Pengaruh pengetahuan, sikap dan dukungan keluarga terhadap diet hipertensi di desa Hulu Kecamatan Pancur Batu tahun 2016. Jurnal Kesehatan Vil 11.No.1, 9-17.

Tjokroprawiro, A., Setiawan, P., Santoso, D., Sogiarto, G., \& Rahmawati, L. (2015). Buku ajar ilmu penyakit dalam:Fakultas kedokteran universitas airlangga rumah sakit pendidikan Dr.Soetomo Surabaya. Surabaya: Airlangga.

Vuvor, F. (2017). Correlation of body mass index and blood pressure of adults of 30-50 years of age in Ghana. Journal of health research \& reviews. Vol.4 Issue 3, 115-121.doi:10.4103/jhrr.jhrr_93_16. 